\begin{tabular}{l}
\hline Jurnal Pakarena \\
Volume 5 Nomor 1, Juli 2020 \\
e-ISSN: 2550-102X dan p-ISSN: $1693-3990$ \\
\begin{tabular}{|l|l|} 
C) (1) This work is licensed under a Creative Commons Attribution \\
4.0 International License
\end{tabular}
\end{tabular}

\title{
Kemampuan Mendesain Motif Batik Mahasiswa Pendidikan Seni Rupa Jurusan Seni Rupa Fakultas Seni Dan Desain Universitas Negeri Makassar
}

\section{Nurjannah Mustakim, Hasnawati, Yabu M}

Keywords :

Kemampuan; mendesain; motif; batik; mahasiswa.

\section{Corespondensi Author}

Seni Pertunjukan, Universitas

Negeri Makassar, Fakultas Seni dan

Desain Jln. Dg. Tata Kampus UNM

Parangtambung

nj4523174@gmail.com

hasnawatidaengngana78@gmail.com yabumallabasa@gmail.com

\section{Artikel}

Received: 12-Maret-2020;

Reviewed: 08-Mei-2020

Revised: 01-Juli-2020

Accepted: 02-Juli-2020

Published: 13-Juli-2020

\begin{abstract}
Abstrak
Penelitian ini bertujuan untuk memperoleh data yang akurat mengenai kemampuan Mahasiswa Angkatan 2017 Program Studi Pendidikan Seni Rupa Fakultas Seni dan Desain Univesitas Negeri Makassar dalam Mendesain Motif Batik. Jenis penelitian ini adalah penelitian evaluatif pada taraf deskriptif kuantitatif yang menjelaskan mengenai kemampuan mahasiswa dalam mendesain motif batik. Variabel dalam penelitian ini adalah kemampuan mahasiswa pendidikan seni rupa dalam mendesain motif batik. Sumber data diperoleh dari Dosen dan Mahasiswa. Populasi pada penelitian ini adalah angkatan 2017 yang terdiri dari 69 orang mahasiswa. Seluruh populasi dijadikan sampel dalam penelitian ini, sehingga teknik pengambilan sampel adalah sampel total. Teknik pengumpulan data digunakan dalam penelitian ini yaitu, observasi, dan dokumentasi. Hasil penelitian menunjukkan bahwa kemampuan mahasiswa angkatan 2017 Program Studi Pendidikan Seni Rupa Fakultas Seni dan Desain Univesitas Negeri Makassar dalam Mendesain Motif Batik termasuk dalam kategori cukup.
\end{abstract}

\section{PENDAHULUAN}

Batik sebagai budaya asli Indonesia yang saat menjadi busana khas dari negara Indonesia. Batik tidak hanya sekedar kain tradisional dengan beragam corak. Di dalam batik juga mengandung sejarah dan nilai-nilai tradisi dari bangsa Indonesia yang sangat berharga. Jika dibandingkan dengan kain-kain biasa batik lebih memiliki nilai seni yang sesuai untuk semua kalangan.

Kain batik digunakan sebagai pakaian yang umumnya dipakai ketika ada acara formal. Kain batik merupakan salah satu kekayaan budaya Indonesia yang tak ternilai harganya. Sejak 2 Oktober 2009 UNESCO menetapkan batik sebagai warisan kebudayaan asli Indonesia. Pengakuan internasional membuat bangsa Indonesia bangga akan budaya batik dan tetap melestarikan keberadaan batik dengan semakin luas di Nusantara (Ihyaul Ulum, 2009).
Sebagai upaya untuk menjaga kelestarian budaya batik dengan mewujudkan kecintaan pada batik dalam menggunakannya sebagai busana. Apalagi sekarang perkembangan batik semakin pesat dan memunculkan motif-motif batik yang beragam sehingga mudah dalam pemilihan corak batik sebagai busana. Selain itu upaya menunjukkan kecintaan pada batik adalah dengan mengetahui jenis-jenis kemudian mengtahui akan sejarah batik dan mengetahui cara membatik. Batik merupakan budaya yang berasal dari tanah Jawa yakni Yogyakarta dan akhirnya menyebar ke seluruh daerah Jawa Tengah seperti Pekalongan, Magelang, dan daerah lainnya. Seiring dengan perkembanganjaman busana batik semakin muncul dengan berbagai jenis corak dan juga desain pakaian yang cantik dan menarik.

Batik termasuk ke dalam salah satu hasil kerajinan tekstil yang sangat dikenal di Indonesia. Selain kaya akan warna dan ragam 
hias, setip motif yang tertuang pada kain batik umumnya juga memiliki makna dan kekhasan tersendiri jadi pembuatan desainnya tidak boleh asal. Meski sepintas terkesan sangat sederhana sebenarnya kegiatan membuat kain batik tidaklah semudah yang dibanyangkan. Khusus untuk mendesain motifnya saja memakan waktu tergantung kesulitan motif yang ingin dibuat.

Mendesain motif batik merupakan salah satu materi yang diajarkan pada mata kuliah kriya tekstil pada angkatan 2017 Pendidikan Seni Rupa Salah satu materi dalam kriya tekstil adalah membuat karya batik, dalam membuat karya batik terlebih dahulu mahasiswa diberi tugas untuk membuat desain atau motif batik. Berdasarkan hal tersebut penulis ingin mengetahui kemampuan mahasiswa angkatan 2017 dalam membuat desain batik.

\section{METODE}

\section{Jenis Penelitian}

Sesuai dengan permasalahan yang telah dikemukakan sebelumnya, maka jenis penelitian ini adalah penelitian evaluatif dengan taraf deskriptif kualitatif. Penelitian evaluatif menjelaskan adanya kegiatan penelitian yang sifatnya mengevaluasi terhadap suatu objek, yang biasanya merupakan pelaksanaan dari suatu rencana. Jadi yang dimaksud dengan penelitian evaluatif adalah penelitian yang bertujuan untuk mengumpulkan informasi tentang apa yang terjadi yang merupakan kondisi nyata mengenai keterlaksanaan rencana yang memerlukan evaluasi.

Penelitian evaluatif merupakan suatu desain dan prosedur evaluasi dalam mengumpulkan dan menganalisis data secara sistematik untuk menentukan nilai atau manfaat (worth) dari suatu praktik. Nilai atau manfaat dari suatu praktik didasarkan hasil pengumpulan data dengan menggunakan standar atau kriteria tertentu yang digunakan secara absolut dan relatif. Penelitian evaluatif bertujuan untuk mengumpulkan informasi tentang apa yang terjadi yang merupakan kondisi nyata mengenai keterlaksanaan rencana yang memerlukan evaluasi. Evaluas yang akan dilakukan dalam penelitian ini adalah mengevaluasi kemampuan mendesain motif batik mahasiswa angkatan 2017.

Penelitian ini dilakukan di Program Studi Pendidikan Seni Rupa Universitas Negeri Makassar Fakultas Seni dan Desain, penelitian yang terfokus pada mahasiswa angkatan 2017 yang berlokasi di Kota Makassar, Jl. Mallengkeri, Parang Tambung, Tamlate, Sulawesi Selatan.

\section{Definisi Operasional Variabel}

Variabel penilaian pada hakikatnya merupakan konsep yang nilainya ingin diketahui oleh peneliti. Tidak sedikit variabel yang terlibat dalam suatu penelitian sifatnya abstrak, dalam arti tidak jelas wujud dan ukurannya, sehingga sulit juga ditentukan nilainya.

Berdasarkan variabel tersebut, maka perlu dilakukan pendefenisian operasional variabel agar memperjelas dan menghindari penafsiran yang keliruh atau salah.

Kemampuan mahasiswa dalam membuat desain motif batik yang tercermin pada orisinalitas desain, keunikan gagasan, komposisi dan artistik.

\section{Populasi dan Sampel}

Populasi adalah keseluruhan objek yang diteliti, yaitu mahasiswa Yang mendesain motif batik di Program Studi Pendidikan Seni Rupa Fakultas Seni dan Desain Universitas Negeri Makassar. Populasi penelitian ini terdiri dari 2 kelas yaitu kelas A 35 orang mahasiswa dan kelas B 34 orang mahasiswa, jadi populasi secara keseluruhan sebanyak 69 orang mahasiswa.

Sugiyono (2008: 118) menjelaskan bahwasanya sampel memiliki arti suatu bagian dari keseluruhan serta karakteristik yang dimiliki oleh sebuah populasi. Keseluruhan populasi menjadi sampel sehingga sampel dalam penelitian ini adalah sampel total.

\section{Teknik Pengumpulan Data}

Teknik penumpulan data dalam penelitian ini adalah sebagai berikut:

\section{Observasi}

Teknik observasi dalam penelitian ini digunakan untuk mengamati langsung karya desain motif batik mahasiswa Seni Rupa Fakultas Seni Dan Desain Universitas Negeri Makassar untuk mengukur kemampuan mendesain motif batik mahasiswa angkatan 2017 Program Studi Pendidikan Seni Rupa Fakultas Seni dan Desain Universitas Negeri Makassar. 
Nurjannah Mustakim, Hasnawati, Yabu M. Kemampuan Mendesain Motif Batik Mahasiswa Pendidikan Seni Rupa Jurusan Seni Rupa Fakultas Seni Dan Desain Universitas Negeri Makassar.

\section{Dokumentasi}

Dokumentasi adalah sebuah cara yang dilakukan untuk menyediakan dokumen yang didapat yaitu hasil karya desain motif batik yang dibuat oleh mahasiswa angkatan 2017 Program Studi Pendidikan Seni Rupa Fakultas Seni Dan Desain Universitas Negeri Makassar.

\section{Teknik Analisis Data}

Menurut Lexy Y. Moleong menjelaskan bahwa analisis data adalah proses mengatur urutan data, mengorganisasikan ke dalam suatu pola, kategori, dan satuan uraian dasar. Teknik analisis data merupakan cara menganalisis data penelitian, termasuk alat-alat statistik yang relevan untuk digunakan dalam penelitian. Analisis data merupakan proses penyusunan data yang diperoleh agar dapat ditafsirkan, digolongkan dalam suatu pola tertentu dengan mencantumkan suatu kode sesuai dengan kategorinya. Lalu diinterpretasikan agar data yang tidak terkumpul tidak menumpuk, dalam disusun sistematis, sehingga memberikan gambaran bermakna mengenai masalah yang diteliti. Data yang telah dikumpulkan kemudian disusun kedalam teks yang diperluas dan dianalisis.

Menurut Tiro (2004: 23) dijelaskan bahwa untuk memperoleh hasil persentase keseluruhan mahasiswa digunakan rumus sebagai berikut:

$$
\begin{array}{|c|}
\hline x=\frac{\mathrm{F}}{\mathrm{N}} \times 100 \% \\
\hline \text { Keterangan: } \\
x: \text { hasil yang dicari } \\
\mathrm{F}: \text { Jumlah frekuensi } \\
\mathrm{N}: \text { Jumlah mahasiswa yang } \\
\text { menjadi sampel penelitian }
\end{array}
$$

Berikut ini adalah klasifikasi kreativitas dalam desain motif batik karya mahasiswa kelas A dan B angkatan 2017 Program Studi Pendidikan Seni Rupa Fakultas Seni dan Desain Universitas Negeri Makassar.

Selanjutnya, menentukan bahwa mahasiswa yang mendapat nilai 91 ke atas sangat baik dalam mendesain motif batik, sedangkan mahasiswa yang mendapat 76-90 dianggap baik, 61-75 dianggap cukup, 51-60 dianggap rendah, dan 0-50 dianggap sangat rendah dalam mendesain motif batik.

\section{HASIL DAN PEMBAHASAN Hasil}

Hasil data yang diperoleh melalui observasi dan dokumentasi (karya mahasiswa) yang merupakan instrumen dalam pengumpulan data maka akan diperoleh jawaban terhadap permasalahan yang diajukan yakni Bagaimana kemampuan mendesain motif batik mahasiswa angkatan 2017 Program Studi Pendidikan Seni Rupa Universitas Negeri Makassar.

Untuk mendapatkan hasil yang akurat mengenai kemampuan mahasiswa dalam membuat desain motif batik, maka 69 mahasiswa angkatan 2017 Program Studi Pendidikan Seni Rupa Fakultas Seni dan Desain Universitas Negeri Makassar yang menjadi sampel dalam penelitian ini telah mengerjakan tugas praktik mata kuliah kriya tekstil dan akan disajikan tabel setiap aspek yang dinilai dari tugas tersebut, selain itu masing-masing tabel akan diberikan komentar untuk memperjelas tabel tersebut. Untuk mengetahui kemampuan mahasiswa dalam mendesain motif batik dapat dinilai dari nilai yang diperoleh mahasiswa dengan kriteria penilaian yaitu orisonalitas desain, keunikan gagasan, komposisi, dan artistik.

Sebagai tim penilai untuk menentukan hasil kemampuan mahasiswa dalam mendesain motif batik mahasiswa angkatan 2017 adalah dosen-dosen

Program Studi Pendidikan Seni Rupa Fakultas Seni Dan Desain Universitas Negeri Makassar yaitu Drs.Aswar, M.Ds. sebagai penilai I, Drs. Lanta L, M.Pd. sebagai penilai II, dan Aulia Evawani Nurdin, S.Pd, M.Pd. sebagai penilai III. Setelah semua data terkumpul selanjutnya dianalisis kemudian ditentukan hasil analisisnya dengan berpatokan pada klasifikasi nilai (rentang penilaian).

Berikut hasil nilai mendesain motif batik mata kuliah kriya mahasiswa Program Studi Pendidikan Seni Rupa Fakultas Seni dan Desain Universitas Negeri Makassar. 


\begin{tabular}{|c|c|}
\hline $86-100$ & Sangat Baik \\
\hline $76-85$ & Baik \\
\hline $66-75$ & Cukup \\
\hline $61-65$ & Rendah \\
\hline$\leq 50$ & Sangat Rendah \\
\hline
\end{tabular}

Berdasarkan hasil karya kemampuan mahasiswa dalam mendesain motif batik pada aspek orisinalitas desain menunjukkan bahwa sebanyak 39 karya $(57.00 \%)$ memperoleh skor 66-75 kategori "cukup", 30 karya $(43.00 \%)$ yang memperoleh skor $61-75$ atau dengan kategori "baik", tidak ada karya memperoleh skor 86-100 kategori "sangat baik", skor 61-65 kategori "kurang", dan skor $\leq$ 50 kategori "sangat kurang". Hal yang menunjukkan bahwa kemampuan mahasiswa pada aspek orisionalitas desain dalam mendesain motif batik mahasiswa angkatan 2017 Program Studi Pendidikan Seni Rupa Fakultas Seni dan Desain Universitas Negeri Makassar dianggap cukup. Hal ini dapat dilihat dari besarnya jumlah karya yang memperoleh skor 66-75 yaitu 39 karya (57.00\%) dibandingkan dengan jumlah karya yang mendapat nilai sangat baik, baik, kurang, sangat kurang.

Berdasarkan hasil karya kemampuan mahasiswa dalam mendesain motif batik pada aspek keunikan gagasan menunjukkan bahwa sebanyak 47 karya (68.00\%) memperoleh skor 66-75 kategori "cukup", 21 karya $(31.00 \%)$ yang memperoleh skor 75-85 atau dengan kategori "baik", 1 karya $(1.00 \%)$ memperoleh skor 61-65 dengan kategori "kuang", tidak ada karya memperoleh skor $\leq 60$ kategori "sangat kurang".

Hal ini yang menunjukkan bahwa kemampuan mahasiswa pada aspek keunikan gagasan dalam mendesain motif batik mahasiswa angkatan 2017 Program Studi Pendidikan Seni Rupa Fakultas Seni dan Desain Universitas Negeri Makassar dianggap cukup. Hal ini dapat dilihat dari besarnya jumlash karya yang memperoleh skor 66-75 yaitu 47 karya $(68.00 \%)$ dibandingkan dengan jumlah karya yang mendapat nilai sangat baik, sangat kurang.

Berdasarkan hasil karya kemampuan mahasiswa dalam mendesain motif batik pada aspek komposisi menunjukkan bahwa sebanyak 49 karya (71.00\%) memperoleh skor 76-85 kategori "cukup", 20 karya $(29.00 \%)$ yang memperoleh skor 76-85 atau dengan kategori "baik", tidak ada karya memperoleh skor 86100 kategori "sangat baik", skor 61-65 kategori "kurang", dan skor $\leq 60$ kategori "sangat kurang". Hal ini yang menunjukkan bahwa kemampuan mahasiswa pada aspek komposisi dalam mendesain motif batik mahasiswa angkatan 2017 Program Studi Pendidikan Seni Rupa Fakultas Seni dan Desain Universitas Negeri Makassar dianggap cukup. Hal ini dapat dilihat dari besarnya jumlah karya yang memperoleh skor 66-75 yaitu 49 karya (71.00\%) dibandingkan dengan jumlah karya yang mendapat nilai sangat baik, baik, rendah, sangat rendah.

Berdasarkan hasil karya Kemampuan mahasiswa dalam mendesain motif batik pada aspek artistik, menunjukkan bahwa sebanyak 50 karya (72.00\%) memperoleh skor 66-75 kategori "cukup", 19 karya $(28.00 \%)$ yang memperoleh skor 76-85 atau dengan kategori "baik", tidak ada karya memperoleh skor 86100 kategori "sangat baik", skor 61-65 kategori "rendah", dan skor $\leq 60$ kategori "sangat rendah". Hal yang menunjukkan bahwa kemampuan mahasiswa pada aspek komposisi dalam mendesain motif batik mahasiswa angkatan 2017 Program Studi Pendidikan Seni Rupa Fakultas Seni dan Desain Universitas Negeri Makassar dianggap cukup. Hal ini dapat dilihat dari besarnya jumlah karya yang memperoleh skor 66-75 yaitu 50 karya (72.00\%) dibandingkan dengan jumlah karya yang mendapat nilai sangat baik, baik, rendah, sangat rendah.

Dari persentase nilai di atas maka dapat disimpulkan bahwa kemampuan mahasiswa angkatan 2017 dalam mendesain motif batik Program Studi Pendidikan Seni Rupa Fakultas Seni dan Desain Universitas Negeri Makassar adalah cukup, bahwa sebanyak 51 karya (74.00\%) memperoleh skor 66-75 kategori "cukup", 18 karya (26.00\%) yang memperoleh skor 76-85 atau dengan kategori "baik", tidak ada karya memperoleh skor 66-75 kategori "cukup", skor 61-66 kategori "rendah", dan skor $\leq 60$ kategori "sangat rendah".

\section{Pembahasan}

Dari hasil penyajian data tersebut menunjukkan bahwa, pada umumnya 
Nurjannah Mustakim, Hasnawati, Yabu M. Kemampuan Mendesain Motif Batik Mahasiswa Pendidikan Seni Rupa Jurusan Seni Rupa Fakultas Seni Dan Desain Universitas Negeri Makassar.

mahasiswa angkatan 2017 dalam mendesain motif batik dapat dikategorikan cukup, sebanyak 18 karya tergolong kategori "baik" dan 51 karya tergolong kategori "cukup", berdasarkan keseluruhan aspek penilaian. Adapun aspek atau kategori yang dinilai, yaitu dari orisinalitas desain, keunikan gagasan, komposisi, dan artistik. Hal ini terbukti dengan adanya 18 karya (26.00\%) memperoleh skor 76-85 kategori "baik", 51 karya $(74.00 \%)$ memperoleh 66-75 kategori "cukup" dan tidak ada karya yang memperoleh skor 86-100 kategori "sangat baik", skor 61- 65 kategori "kurang", dan skor $\leq 60$ kategori "sangat kurang".

Berdasarkan aspek orisionalitas desain yang memperoleh skor 66-75 sebanyak 39 karya (57.00\%) termasuk dalam kategori "cukup", yang memperoleh skor 76-85 sebanysak 30 karya $(43.00 \%)$ termasuk dalam kategori "baik", tidak ada karya memperoleh skor 86-100 kategori "sangat baik", skor 61-65 kategori "kurang", dan skor $\leq 60$ kategori "sangat kurang".

Dari hasil penilaian menunjukkan bahwa 38 dari 69 populasi dianggap cukup. Hal ini bisa dilihat dari besarnya jumlah karya yang memperoleh skor 66-75 yaitu (57.00\%) dibandingkan dengan jumlah karya yang mendapat nilai sangat baik, kurang, dan sangat kurang.

Berdasarkan aspek keunikan gagasan yang memperoleh skor 66-75 sebanyak 47 karya $(68.00 \%)$ termasuk dalam kategori "cukup", yang memperoleh skor 76-85 sebanysak 21 karya $(31.00 \%)$ termasuk dalam kategori "baik", yang

memperoleh skor 61-65 sebanyak 1 karya termasuk dalam kategori "kurang", tidak ada karya memperoleh skor 86-100 kategori "sangat baik", dan skor $\leq 60$ kategori "sangat kurang".

Dari hasil penilaian menunjukkan bahwa 47 dari 69 populasi dianggap cukup. Hal ini bisa dilihat dari besarnya jumlah karya yang memperoleh skor 66-75 yaitu (68.00\%) dibandingkan dengan jumlah karya yang mendapat nilai sangat baik, kurang, dan sangat kurang.

Berdasarkan aspek komposisi yang memperoleh skor 66-75 sebanyak 49 karya (71.00\%) termasuk dalam kategori "cukup", yang memperoleh skor 76-85 sebanysak 20 karya (29.00\%) termasuk dalam kategori "baik", tidak ada karya memperoleh skor 86100 kategori "sangat baik", skor 61-65 kategori "kurang", dan skor $\leq 60$ kategori "sangat kurang".

Dari hasil penilaian menunjukkan bahwa 49 dari 69 populasi dianggap cukup. Hal ini bisa dilihat dari besarnya jumlah karya yang memperoleh skor 66-75 yaitu (71.00\%) dibandingkan dengan jumlah karya yang mendapat nilai sangat baik, kurang, dan sangat kurang.

Berdasarkan aspek artistik yang memperoleh skor 66-75 sebanyak 50 karya (72.00\%) termasuk dalam kategori "cukup", yang memperoleh skor 76-85 sebanysak 19 karya $(28.00 \%)$ termasuk dalam kategori "baik", tidak ada karya memperoleh skor 86100 kategori "sangat baik", skor 61-65 kategori "kurang", dan skor $\leq 60$ kategori "sangat kurang".

Dari hasil penilaian menunjukkan bahwa 50 dari 69 populasi dianggap cukup. Hal ini bisa dilihat dari besarnya jumlah karya yang memperoleh skor 66-75 yaitu $(72.00 \%)$ dibandingkan dengan jumlah karya yang mendapat nilai sangat baik, kurang, dan sangat kurang.

\section{SIMPULAN DAN SARAN Kesimpulan}

Berdasarkan hasil penelitian yang telah dihasilkan mengenai kemampuan mahasiswa Program Studi Pendidikan Seni Rupa Fakultas Seni dan Desain Universitas Negeri Makassar dalam mendesain motif batik, maka dapat disimpulkan bahwa kemampuan mahasiswa dalam aspek orisinalitas desain, keunikan gagasan, komposisi, dan artistik tergolong relatif bervariasi, sebanyak 51 karya $(74.00 \%)$ memperoleh skor 76-90 tergolong dalam kategori “cukup", 18 karya $(26.00 \%)$ yang memperoleh skor 61-75 tergolong dalam kategori "baik", Kemampuan tersebut tercermin dari pencapaian perolehan nilai mahasiswa yang terdapat dalam persentase nilai (kategori sangat baik, baik, cukup, kurang, dan sangat kurang). 


\section{Saran}

Berdasarkan hasil penelitian dan kesimpulan yang telah duraikan di atas, maka penulis mengajukan saran yaitu Perlu banyak eksplorasi dalam berkarya, karena salah satu kurangnya nilai orisinalitas dalam karya adalah terlalu banyak aspek yang ditiru ketimbang aspekaspek kebaruan. Selain itu, masih ada faham dalam membuat desain batik yang memperbolehkan pengulanganpengulangan bahkan memperbanyak pengulangan, terutama desain-desain yang sifatnya tradisi. Oleh karena itu, perlu banyak berekplorasi dalam berkarya sehingga motif-motif yang dihasilkan dapat dikembangkan. Selain itu, juga disarankan untuk meneliti lebih jauh faktor-afaktor apa saja yang menyebabkan rendahnya aspek orisinalitas dan aspek keunikan gagasan dalam mendesain batik.

\section{DAFTAR PUSTAKA}

Moleong, Lexy J. 2006. Metode Penelitian Kualitatif . Bandung: Rosdakarya.

Sugiyono. 2008. Metode Penelitian Pendidikan (Pendekatan Kuantitatif, Kualitatif, dan R\&D). Bandung : Alfabeta.

Tiro, Muhammad Arif. 2004. Bagaimana Aku Berpikir?. Makassar: Andira Publisher.

Ulum, Ihyaul. 2009. Batik Dan Kontribusinya Terhadap Perekonomian Nasional. Jurnal Bestari, nomor 42 tahun 2009. 